Ege Journal of Medicine / Ege Tıp Dergisi 2016;55(2):89-91

\title{
Komplike Fournier gangreninde multidisipliner yaklaşım
}

\section{Multidisciplinary approach for complicated Fournier gangrene}

\author{
Burhan Mayir $^{1} \quad$ Asım Uslu $^{2} \quad$ Yeliz Akpınar Mayir ${ }^{3} \quad$ Tuğrul Çakır $^{1} \quad$ Arif Aslaner $^{1}$ \\ Uğur Doğan ${ }^{1} \quad$ Umut Rıza Gündüz ${ }^{1} \quad$ Senem Akpınar ${ }^{4}$
}

${ }^{1}$ Antalya Eğitim ve Araştırma Hastanesi, Genel Cerrahi Kliniği, Antalya, Türkiye

${ }^{2}$ Antalya Eğitim ve Araştırma Hastanesi, Plastik ve Rekonstrüktif Cerrahi Kliniği, Antalya, Türkiye

${ }^{3}$ Antalya Eğitim ve Araştırma Hastanesi, Kadın Hastalıkları ve Doğum Kliniği, Antalya, Türkiye

${ }^{4}$ Antalya Eğitim ve Araştırma Hastanesi, Anesteziyoloji ve Reanimasyon Kliniği, Antalya, Türkiye

\section{Öz}

Fournier gangreni perineal ve genital bölgelerden başlayarak fasya boyunca yayılan enfeksiyöz bir hastalıktır. Tedavide gecikme ve yetersiz debridmanlar hastalığın ölümcül seyretmesine sebep olabilir. 23 yaşında erkek hasta, gluteal ve skrotal bölgeyi tutan kötü kokulu, akıntılı lezyon nedeniyle başvurdu. Sol bacağında renk değişikliği vardı. Hasta başvuru anında septik şokta idi. Gluteal ve skrotal bölgeyi içeren debridman sonrası hastanın genel durumu düzelmedi. Bacaktaki lezyonun Fournier gangrenine bağlı olduğu düşünülmesinin ardından, skrotumdan ayakucuna kadar yapılan çok geniş bir debridman sonrası iyileşme gözlendi. Daha sonra rekonstrüktif girişim uygulandı. Fournier gangreninde ana lezyondan uzakta bile olsa tüm lezyonların debridmanı ve bu hastaların, anesteziyoloji ve reanimasyon, üroloji, kadın hastalıkları, plastik ve rekonstrüktif cerrahi uzmanları ile birlikte multidisipliner bir yaklaşımla tedavisi gerekir.

Anahtar Sözcükler: Fournier gangreni, nekrotizan fasiit.

\section{Abstract}

Fournier gangrene is an infectious disease originates from perineal and gluteal region spreading throughout the fascia. Life threatining results can be seen due to insufficient debridation or delay in treatment. A 23-year-old male patient admitted to hospital with an effusive lesion around gluteal and scrotal area which has a bad smelling. There was a color change at the left leg. He was in septic shock status. General condition of patient didn't change after debridation of gluteal and scrotal region. Consideration of the lesion as Fournier gangrene, wide debridation from scrotum to toe secondary was performed and improvement was observed. Afterwards reconstructive approach was applied. Debridement of all lesions even if they are apart from Fournier gangrene area is essential and these patients should be treated with multidisciplinary approach including general surgery, anesthesiology and reanimation, urology, gynecology, plastic and reconstructive surgery specialists.

Keywords: Fournier gangrene, necrotizing fasciitis.

\section{Giriş}

Fournier gangreni perineal bölgeden başlayarak fasya ve çevresindeki yumuşak dokunun nekrozu ile karakterize enfeksiyöz bir hastalıktır (1). Hızlı ilerleyebilen ve ölümcül seyredebilen bu hastalıkta erken tanı ve erken cerrahi girişim çok önemlidir. Hastalık perineal ve genital bölgelerden başlasa da tüm fasya boyunca ekstremiteye, intraabdominal alana ve retroperitoneal alana uzanabilir. Tedavide gecikme veya tam olmayan debridmanlar hastalığın ölümcül seyretmesine sebep olabilir $(2,3)$.

Yazışma Adresi: Burhan Mayir

Antalya Eğitim ve Araştırma Hastanesi, Genel Cerrahi Kliniği, Antalya, Türkiye

Makalenin Geliş Tarihi: 01.02.2015

Kabul Tarihi: 20.04.2015
Bu makalede, septik bir tabloda başvuran, yapılan yetersiz cerrahi girişim sebebiyle durumunda düzelme olmayan ve sonrasında tekrar opere edilen yaygın tutulumlu bir Fournier gangreni olgusu sunulmaktadır. Genel cerrahi, plastik ve rekonstrüktif cerrahi, anesteziyoloji ve reanimasyon uzmanlarının multidisipliner yaklaşımı ile hastaya yapılan girişimler aktarılmaktadır.

\section{Olgu Sunumu}

23 yaşında erkek hasta 1-2 gündür olan ateş, genel durum bozukluğu, kalça ağrısıyla başvurdu. Hastanın özgeçmişinde herhangi bir hastalık, cerrahi girişim ya da travma yoktu. Başvuruda TA: $70 / 50 \mathrm{mmHg}$, Nabız 110/dk, Ateş: $39.6^{\circ} \mathrm{C}$ idi. Sol gluteal bölgeden başlayarak skrotuma kadar uzanan, kötü kokulu, 
nekrotik alanlar içeren akıntılı lezyon izlendi. Laboratuvar incelemelerinde patolojik olarak BUN $62 \mathrm{mg} / \mathrm{dL}$, kreatinin

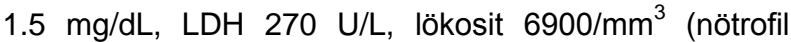
\%92.3), CRP $341 \mathrm{mg} / \mathrm{L}$ olarak bulundu. Fournier gangrenine bağlı septik şok tanısıyla operasyona alındı. Gluteal ve skrotal bölgedeki tüm nekrotik dokular testisler açıkta kalacak şekilde çıkarılarak geniş debridman uygulandı. Anüs çevresinin korunmuş olması sebebiyle kolostomi açılmadı. Yara yeri pansumanla kapatılarak yoğun bakımda takibe alındı. Yoğun bakımda entübe olarak takip edilerek, norepinefrin, dopamin, dobutamin tedavisi başlandı. Enfeksiyon hastalıkları önerisi doğrultusunda ampirik olarak daptomisin 1×350 mg/gün iV, meropenem 3x500 mg/gün iV, klindamisin 4x600 mg/gün başlandı.

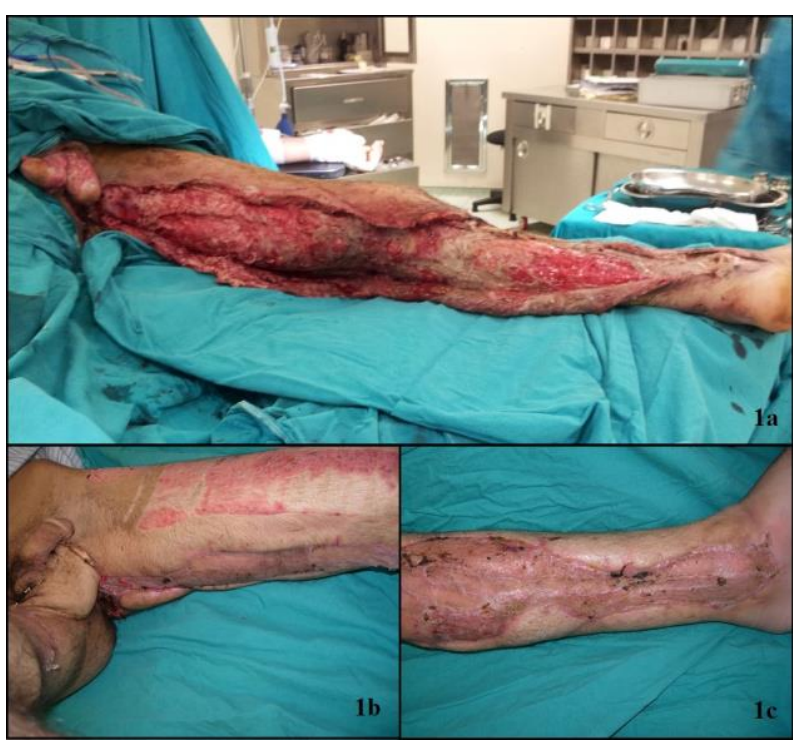

Şekil-1 a.Fournier Gangreni için kasıktan ayak ucuna kadar yapılan geniş debridman, b. Skrotum ve bacaktaki yaraların rekonstrüksiyon sonrası görünümü, c. Bacaktaki yaraların rekonstrüksiyon sonrası görünümü.

Yoğun bakımda ameliyat sonrası birinci gün lökosit $2800 / \mathrm{mm}^{3}$, PLT 63000/mm³ , D-dimer 1270, fibrinojen 476, BUN 58, kreatin 1.35, albümin 1.8 olarak saptandı. Hastanın septik şok tablosunda belirgin düzelme izlenmedi. Ateş yüksek seyrederken, inotrop desteğe rağmen TA düşük seyretti. Takiplerde trombosit $11000 / \mathrm{mm}^{3}$ e kadar geriledi. Debridman yapılan bölgede nekrotik doku izlenmemekle birlikte sol alt ekstremitede uyluktan ayak dorsaline kadar uzanan renk değişikliği izlenmeye başlandı. Hastanın takiplerde ateşi $40^{\circ} \mathrm{C}$ 'ye kadar yükseldi. Derideki renk değişikliğinin deri nekrozu şekline dönüşmeye başlaması sonrası, bu durumun nekrotizan fasiite bağlı olduğu düşünülerek hasta ilk operasyon sonrası 5. gün tekrar opere edildi. Operasyonda sol bacak uyluk iç kısımdan başlayarak ayak parmaklarına kadar uzanan fasyal nekroz izlendi. Tüm nekrotik dokular çıkarılacak şekilde çok geniş debridman yapıldı (Şekil-1a,b,c). İkinci operasyon sonrası yoğun bakım izlemlerinde hastanın genel durumunda düzelme izlendi. Beşinci gün inotrop desteği tamamen kesildi, 10. gün ekstübe edildi. Takiplerde yara yerinde belirgin iyileşme gözlendi.

Servis izleminde tamamen enteral beslenebilen hastaya günlük kuru gazlı bez ile pansumanlar devam edildi. Antibiyotik tedavisi 21 gün sürdürüldü. Daha sonra seftriakson 2x1 g/gün başlandı. Genel durumunun iyi olması ve yara yerinde belirgin granülasyon gelişmesi üzerine, yara yeri rekonstrüksiyonu amacıyla Plastik ve Rekonstrüktif Cerrahi kliniğine devir edildi. Rekonstrüksiyonda öncelikle testislerin kapatılması planlandı. Testisler üzerindeki fibrotik, granüle dokular debride edildikten sonra sağ uyluk medialinden yapılan medial sirkümfleks femoral arter bazlı ada flep kaldırılarak testislerin üzeri kapatıldı. Flep donör alanı primer onarıldı. Aynı seansta bacaktaki fibrotik granüle alanlar kürete edildi. Derinin dekole olduğu yerlerde deri altı ve alttaki kas üzeri kürete edildi ve böylece derinin tabana yapışması sağlandı. Açık yaralar sütürlerle daraltılabildiği kadarıyla daraltıldı. Operasyon sonrasında uyluk ve bacaktaki doku defekti alanlarına günlük antibiyotikli meşlerle günlük pansuman yapıldı. Flebin testislere tam olarak yapışması için 1 hafta beklendi. İkinci seansta sağlıklı sağ uyluk ve bacaktan dermatomla deri grefti alındı. Greftle uyluk medial süperioru hariç tüm alanlar greftlendi. Operasyon spinal anestezi altında yapıldığı ve anestezik alanda greft alacak yer kalmadığı için uyluk süperiomediali açık bırakıldı. Greft donör alanı iyileştikten sonra, 3. operasyonda uyluktan daha önce greft alınarak epitelize olmuş donör alandan tekrar greft alındı ve uyluk medial süperiorundaki açık alan greftlendi. Takibinde hastanın tüm greftleri sorunsuz olarak iyileşti.

Hastadan tıbbi verilerinin yayınlanabileceğine ilişkin yazılı onam belgesi alındı.

\section{Tartışma}

Hastalığın mortalitesi günümüzde teşhis ve tedavi yöntemlerindeki gelişmelere rağmen \%16-40 arasında değişmektedir (4). Tedavide, agresif hemodinamik stabilizasyon, parenteral geniş spektrumlu antibiyotikler ve acil ve agresif cerrahi debridman uygulanmalıdır (10). Fasyal nekroz hızının saate $2-3 \mathrm{~cm}$ kadar yüksek olabildiği düşünüldüğünde erken cerrahi girişimin ne kadar önemli olduğu anlaşılmaktadır (5). Hastamızda da ilk cerrahi girişimin erkenden yapılmasına karşın bacaktaki fasiitin ilk operasyonda görülmemesi, sonrasında bunun tüm bacağa hızla yayılması sebebiyle hasta septik şok tablosundan çıkamamış, ancak ikinci operasyondan sonra düzelme sağlanmıştır. Canbaz ve ark. (4) çalışmalarında, tedavi öncesi geçen sürenin ölümcül seyreden olgularda anlamlı şekilde uzun olduğunu ve bu süre beş günü aştığında mortalitenin arttığını bildirmektedirler. 
Cerrahideki amaç tüm nekrotik dokular çıkarmak, böylece nekroz ve enfeksiyonun ilerlemesini durdurmak, sistemik toksisiteyi azaltarak sepsisi önlemektir. İlk debridmandan sonra hastanın klinik-laboratuvar bulgularında düzelme saptamazsa halen nekrotik dokunun bulunduğunu ya da intraperitoneal, retroperitoneal yayılım olabileceği düşünülmelidir. Bizim olgumuzda ilk debridman sonrası hastanın durumunda beklenen düzelme olmamış, sonrasında bacaktaki patolojinin saptanmasıyla gerekli girişimin yapılması ile hastanın durumunda belirgin düzelme izlenmiştir. Olgumuzdaki gibi erken dönemdeki belirgin olmayan deri lezyonları tanıyı zorlaştırarak hastalığın atlanmasına yol açabilmektedir. Bu yüzden esas patolojik bölgeden uzakta bile olsa deride saptanan lezyonların Fourneir gangrenine bağlı olabileceği düşünülmeli, geniş debridanman yapılmalıdır.

Fournier gangreninde, anorektal bölge ve sfinkter tutulmuşsa, çok geniş perineal yaralar varsa veya fekal kirlilik varsa kolostomi açılması önerilmektedir (1). Öztürk ve ark. (6), kolostomili veya kolostomisiz olguların benzer klinik sonuçlara sahip olduğunun bildirmiştir. Hastamızda anal bölgenin korunmuş olması sebebiyle kolostomi açılmamıştır. Yara yerinde iyileşme sonrası o bölgenin rekonstrüksiyonu önemlidir. Küçük yaraların sekonder iyileşme ile kapanması mümkün olmakla birlikte büyük çaplı yaralarda greft uygulanması gerekebilmektedir. En çok tercih edilen yöntem split-thickness deri greftleridir (7). Skrotum rekonstrüksiyonu için ise iç uyluk flebi, pediküllü derin inferior epigastrik perforatör flep, anterolateral uyluk flebi, medial sirkumfleks femoral arter perforatör flebi gibi farklı flep çeşitleri kullanılabilir. Medial sirkumfleks femoral arter perforatör flebinin, diğer perforatör fleplere göre skrotuma kolaylıkla uzatılabilme, skrotal kıvrımların uygun şekilde yapılabilmesi, donör alanında minimal iz bırakması gibi avantajları vardır (8). Yara kapanmasında diğer seçenekler vakum yardımlı kapama ve hiperbarik oksijen tedavisidir $(9,10)$. Sonuç olarak, hızlı ilerleyen, ölümcül seyredebilen hastalıkta erken ve geniş debridman uygulanmalıdır. Bu hastalık sadece gluteal ve skrotal bölgeyi tutan basit bir enfeksiyonu olarak görülmemeli, şüphelenilen tüm lezyonların açılarak görülmesi, radikal debridmanı sağlanmalıdır. Bu hastaların genel cerrahi, plastik ve rekonstrüktif cerrahi, üroloji, kadın hastalıkları, anesteziyoloji ve reanimasyon uzmanları ile birlikte multidisipliner bir yaklaşımla tedavisi yapılmalıdır.

\section{Kaynaklar}

1. Oymacı E, Coşkun A, Yakan S, Erkan N, Uçar AD, Yıldırım M. Evaluation of factors affecting mortality in Fournier's Gangrene: Retrospective clinical study of sixteen cases. Ulusal Cer Derg 2014;30(2):85-9.

2. Jeong HJ, Park SC, Seo IY, Rim JS. Prognostic factors in Fournier gangrene. Int J Urol 2005;12(12):1041-4.

3. Ünal B, Koçer B, Özel E, et al. Fournier gangrene. Approaches to diagnosis and treatment. Saudi Med J 2006;27(7):1038-43.

4. Canbaz H, Çağlıkülekçi M, Altun U, et al. Fournier's gangrene: Analysis of risk factors affecting the prognosis and cost of therapy in 18 cases. Ulus Travma Acil Cerrahi Derg 2010;16(1):71-6.

5. Levenson RB, Singh AK, Novelline RA. Fournier gangrene: Role of imaging. Radiographics 2008;28(2):519-28.

6. Ozturk E, Sonmez Y, Yılmazlar T. What are the indications for a stoma in Fournier's gangrene? Colorectal Dis 2011;13(9):10447.

7. Yılmazlar T. Fournier Gangreni: Sinsi, öldürücü, ancak tedavi edilebilir hastalık. Kolon Rektum Hast Derg 2012;22(2):45-9.

8. Coskunfirat OK, Uslu A, Cinpolat A, Bektas G. Superiority of medial circumflex femoral artery perforator flap in scrotal reconstruction. Ann Plast Surg 2011;67(5):526-30.

9. Czymek R, Schmidt A, Eckmann C, e al. Fournier's gangrene: Vacuum-assisted closure versus conventional dressings. Am J Surg 2009;197(2):168-76.

10. Shaw JJ, Psoinos C, Emhoff TA, Shah SA, Santry HP. Not just full of hot air: Hyperbaric oxygen therapy increases survival in cases of necrotizing soft tissue infections. Surg Infect 2014;15(3):328-35. 